\title{
13
}

\section{THE ROLE OF GREENSPACES IN URBAN DESIGN THEORIES IN FRANCE}

\author{
Valter Balducci
}

Since the introduction of the concept of sustainable development (WCED 1987), there has been a wide range of different proposals, programs, and projects calling for a close relationship between the city and nature. Many of these aim to translate the notion of sustainability into urban structures and architectural types or shapes, working with nature, or more precisely, with green urban areas. These pages synthesize some of the results of research on greenspaces in the urban design theories of the modern era, particularly in France. Questioning the notion of greenspace and its role in architectural and urban theory poses some methodological difficulties. These include the inherent complexity of the definition of 'nature' in the historical context or the sheer variety of words used in architectural and urban thought (like nature, green, park, garden, countryside, etc.) or the variety of sources (theoretical texts, planning programs, urban and landscape projects) or scales (from gardens to territory). These methodological questions will be the subject of a future publication.

This chapter has three parts: first, nature considered as an urban system that is superimposed on the existing town and anticipates its development; second, natural space considered as a substratum for modernist urban shape and as a framework for urban planning; and, finally, natural spaces as ecological systems for redesigning urban areas and as a preparation for the future transformation of urban territories.

\section{The Search for an Urban System}

Green urban areas have always been essential elements in the city, but it was in the 18th century that this type of urban space was first considered as an element for the design or modification of the city. The theorist Marc-Antoine Laugier (1713-1769) developed an original theory of beautification of cities based on principles derived from nature. Laugier's nature is an idealized nature, with themes and shapes coming from picturesque gardens, rich in landscape effects, depths, points of view, plant elevations, and horizon lines. For Laugier, "You must look at a city like a forest. The streets of the former are the pathways of the latter; and they must be traced in the same way." However, this is not a forest like any other: 
The plan must be drawn by Le Nôtre (...); that here we see a star-shape, a crow's foot, on this side a herringbone road, on the other, fan-shaped roads; further away, parallel lines; everywhere crossroads of different designs and shapes can be found.

(Laugier 1755, p. 222)

These planted, rectilinear paths, intersecting at roundabouts, provide the layout for public spaces during the extension of French towns, which were opened up to the surrounding countryside, after the demolition of their former military ramparts. If in Versailles there is a clear analogy between the structure of the avenues in the park and the planted boulevards in the town, in several plans for urban extension the planted avenues play a role in the orientation and structuration of the new urban fabric (Figure 13.1).

This planted boulevard constitutes the archetype of the urban axis developed in the mid19th century during the transformations of Paris under Napoleon III. At this period, Paris underwent a significant reorganization via the introduction of new infrastructure networks, for the circulation of people and goods and connection with city services. The layout of this network was defined by greenspaces; thanks to the work of Adolphe Alphand (1817-1891), a classification of different urban greenspaces was defined: the boulevard, the wood, the park, the square, and the garden (Alphand 1867-1873). In Paris, this approach was continued by Eugène Hénard (1849-1923). In his proposals at the turn of the 20th century, Hénard planned the development of a system of natural spaces inherited from Alphand's work, through the construction of nine new, large parks covering an area of around 10 hectares on the outskirts of the city (Hénard 1903-09).

\section{Park System}

The publication of Grandes villes et systèmes de parcs in 1908 by Jean-Claude-Nicolas Forestier (1861-1930) disseminated in France the work of American landscape architect Fredrick Law

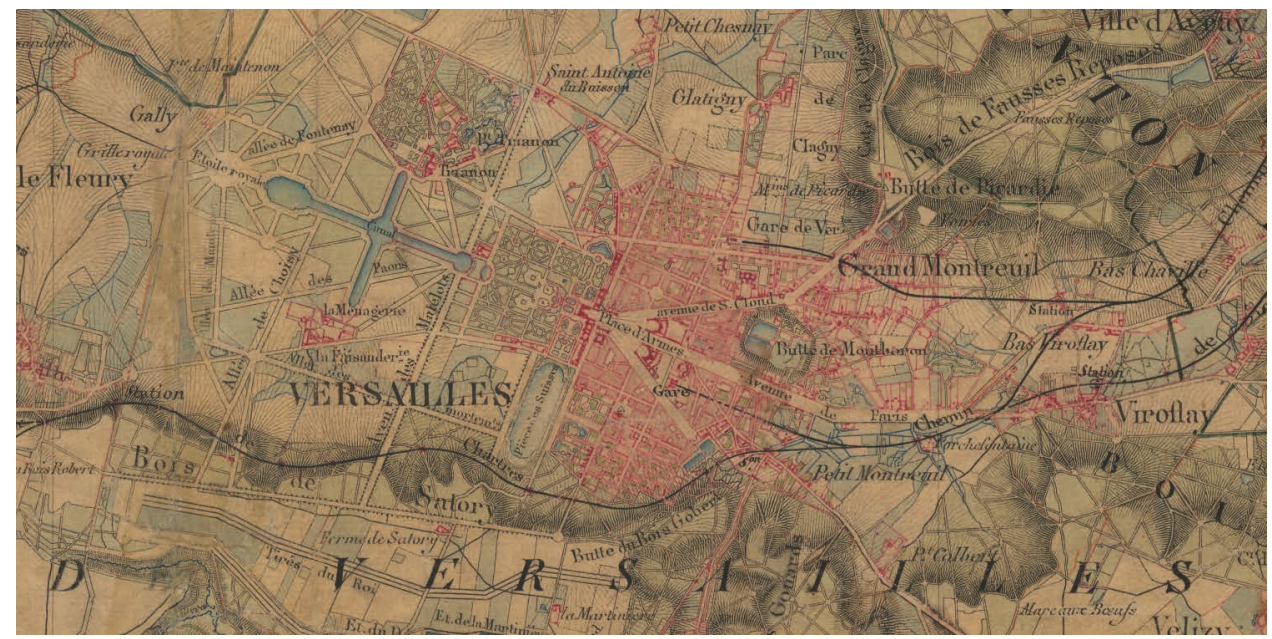

FIGURE 13.1 The park, the castle, and the city of Versailles, extract from the Carte de l'État Majeur, 1866 (https://remonterletemps.ign.fr). 
Olmsted (1822-1903). Since he building of Prospect Park in Brooklyn in 1866, Olmsted had innovated with the introduction of the parkway, integrating all the city's greenspaces, from parks to peripheral or abandoned sites, into a continuous urban network, the park system. The parkway, then developed as the greenway and the riverway, separated the circulation of pedestrians and car traffic into parallel corridors, while also creating a planted strip that gave the city the benefits of a park. In Boston, Olmsted produced what would be nicknamed the 'Emerald Necklace', a continuous arrangement of existing parks brought together as a single large regional park (see The Papers of Olmsted 1997). Forestier gave the concept of the park system a regional dimension (Forestier 1908). His system of parks included a set of spaces ranging from large nature reserves protected at a territorial level, such as large urban parks, recreation grounds, small parks, neighborhood gardens, all connected by a network of avenues. Although it also included forest, rivers, valleys, or large rock formations, establishing a continuity between the city and its surrounding region. In Forestier's plans for cities like Rabat, Habana, or Paris, the interconnected greenspaces act as a structuring element. The key space of the Forestier park system is the avenue-promenade. This differs from the simple road infrastructure because of "the character, the pleasure, the efficiency and the capacity" it has, due to its size and to the use of natural elements, such as aligned trees and lawns (Figure 13.2).

Forestier designed a park system project for Paris in 1923. Unlike the work of Haussmann, which only dealt with the center of the city, Forestier's park system was concerned with the extended metropolis. The project gave city dwellers a group of different greenspaces where they could take a walk and at the same time promoted certain urban public health principles characteristic of the time, such as the circulation of the wind to improve the ventilation of the city, or physical activity in the open air, in order to improve the health of the citizens. The approach was three-dimensional, with the axial perspectives reinforced by the planted lines of trees and vegetation. The viewpoints onto the surrounding landscape were

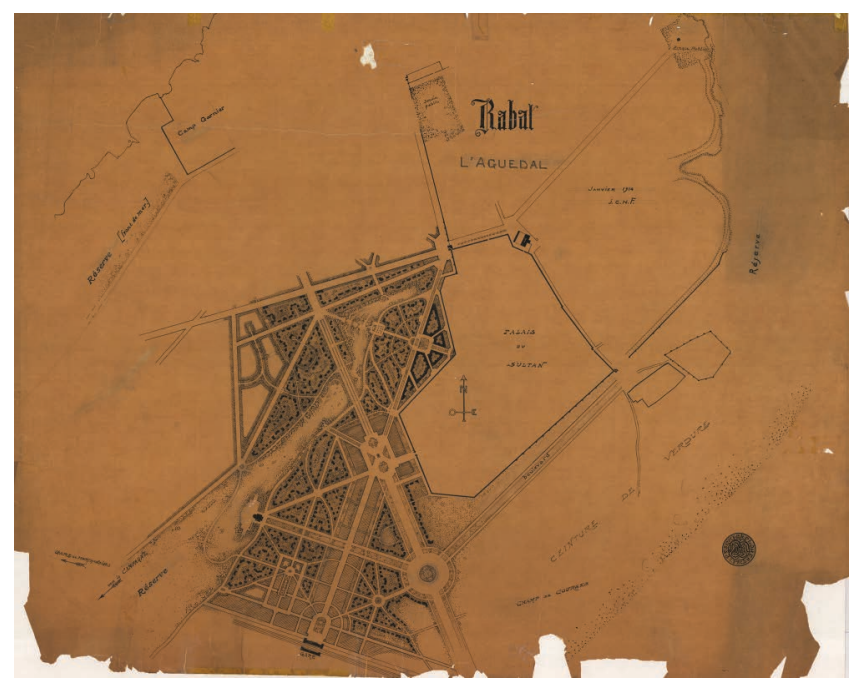

FIGURE 13.2 Jean-Claude-Nicolas Forestier, housing estate at Aguedal, Rabat, Maroc, 1914 (Fonds Forestier. SIAF/Cité de l'architecture et du patrimoine/Archives d'architecture du XXe siècle). 
also carefully researched along with the importance given to pedestrians or the emphasis of the natural topography. These elements are also close to the urban design principles of architects like Léon Jaussely (1875-1932) or Jacques Greber (1882-1962) and other architects from the Société française des urbanistes (founded in 1911).

The replacement of the fortifications that encircled Paris was an opportunity for Forestier, who proposed in 1909 that they be substituted by a sequence of parks forming a ring around the city. His proposals were part of the basis for the work of the Commission pour l'extension de Paris, led by Marcel Poëte and Louis Bonnier (Préfecture Département Seine 1913). The commission's report led to a competition in 1919, won by Léon Jaussely. Jaussely's plan combined the principle of decentralization of garden cities and Forestier's concentric ring model with a form of insertion of the countryside into the city of Paris. This also reflects the more radical and widely used approach adopted by Bruno Möhring (1863-1929), Rudolf Eberstadt (1856-1922), and Richard Petersen (1865-1946) in their project for Greater Berlin in 1911, where concentric urbanized rings alternate with cones, allowing the introduction in the metropolitan area of fragments of countryside, woodland or forest (Eberstadt 1920, pp. 232-233), or in following plans, like the plan for Aachen proposed in 1920 by Karl Henrici (1842-1927), Gustav Schimpff (1871-1919), and Carl Sieben (1864-1927).

The idea that natural spaces are given the role of breaks in the urban continuum had already been suggested by the urban reformer John Claudius Loudon (1783-1843), who, in 1829, put forward the idea that the city (London in particular) "may be extended in alternate mile zones of buildings, with half mile zones of country or gardens" (Loudon 1929). This idea of creating breathing spaces into the city contributed to the garden city theory by Ebenezer Howard (1850-1928) and its rapid introduction in France by Georges Benoit-Levy (1880-1971). For Benoît-Lévy, the garden city theory offered an alternative to disorderly industrial development, allowing a regional dispersion of habitats and production activities through isolated garden cities surrounded by agricultural land (Benoit-Lévy 1904). For him,

the garden city is a model, modern city, [...] It is a city in which each dwelling is in the middle of a garden, in which each district is surrounded by a park, itself surrounded by a vast strip of fields and forests.

(Benoit-Lévy 1910, p. 157)

It corresponds to a social need, and according to Georges Risler (1853-1941),

The natural need for sun and pure air, for greenery and flowers is such an imperative for man that it was in a large garden, "the earthly paradise," that all religions have believed that the first men should be placed.

(Risler et al. 1916, p. 375)

The garden represented the ideal of nature: providing a connection between private and public spaces and also between work and leisure, as working the soil in the gardens was considered to be an ideal leisure activity for the inhabitants. However, the transcription of the garden city model had certain differences: the French Cité jardin is less the self-contained city as proposed by Howard and more a developed version of the working-class town and an 
element of the planned expansion of the city. The Office public d'habitations à bon marché de la Seine, an organization for accessible housing whose president was Henri Sellier (1883-1943), implemented a project based on this approach, building 11 Cités jardin around Paris, as from 1921 (Sellier s.d.).

\section{Nature as Substratum and Framework}

In the context of the debate on modern urban planning in the 20th century, the natural space assumes the role of a substrate for new urban forms and becomes a part of urban and regional planning.

\section{Open Ground}

According to the theories on health and hygiene, getting the sun and wind to come through the urban fabric was essential. In their study of Paris, which was begun in 1913 and published in La science des plans des villes in 1928, Adolphe-Augustin Rey (1864-1934), Justin Pidoux, and Charles Barde (Rey et al. 1928) proposed a reform of the morphology of urban fabric, in order to increase exposure to the sun and prevailing winds. The consequent separation between the roads and buildings creates an intermediate space that Rey thought of as natural. In a different way, and with many other ambitions and objectives, the numerous projects for the modern city also adopted Rey's heliothermic approach, affirming a new role for the space of the ground. This space reinforces the relationships between the shapes of the large-scale buildings, which had been transformed into architectural objects, independent from the street itself. In 1941, André Gutton (1904-2002) wrote in La Charte de l'urbanisme (a charter for town planning) that "landscapes must be furnished with monuments" (Gutton 1941). Liberated from its interdependence with the volumes of the buildings, the urban ground could now have its own specific project. Preferably designed as a landscaped area, the ground was considered as a space for leisure, with an important social function. Le Corbusier (1887-1965) specified its characteristics in the Athens Charter: "the new green areas must serve clearly defined purposes: accommodating kindergartens, schools, youth centres or any buildings for community use, closely connected to people's homes" (Le Corbusier 1943, n. 37), while leisure time is associated with the presence of local parks, forests, sports facilities, and existing natural sites, like rivers, mountains, valleys, and lakes (Ibidem, n. 3840). This continuous landscape from the city to the territory was irrigated by a hierarchical network of roads, the Chandigarh $7 \mathrm{~V}$, which was a premonition of the territorial development of the following decades: a hierarchical road network superimposed on a continuous ground but delimited by large sectors of habitat or production, with the greenways reduced to the vegetated corridors along the rivers (Le Corbusier 1945, 1959, p. 49). André Gutton in 1950 specified that "it is not a question of interpreting nature, but of understanding and copying it, and especially of understanding its true scale" (Gutton 1950, p. 191). He refused the simple accumulation of trees, the profusion of paths, and the subdivision of the ground into "petty flowerbeds"; he advocated for a reduction in the fragmentation of the ground into separate elements, in order to "lay the houses on green lawns which are as large as possible" (Gutton 1950, p. 191).

On the large housing estates such as the Grandes Terres à Marly-le-Roi (1952-1960) by Marcel Lods (1891-1978), the ground space constitutes one of the main urban elements, 
endowed with its own autonomy and its own design, but it is still thought of in terms of its visual, landscaped aspects and as a space for leisure activities. These areas are designed as urban amenities, without any ecological or environmental functions. However, even if their definition is restricted to their social role, these greenspaces are nonetheless places that contribute to the construction of a unique urban landscape. Xavier Arsène-Henry (19192009) analyzed the morphology of large housing complexes as being composed of three elements: open ground, sculpture-like buildings, and transitional spaces (Arsène-Henry 1961). Topological relationships are established between these three elements. Public space has a key role: it can be "shaped," with compositions of buildings more or less closely or distantly placed together, creating points of intensity, compression of the space, or alternating between closed or open viewpoints (Taupin 1964; Figure 13.3).

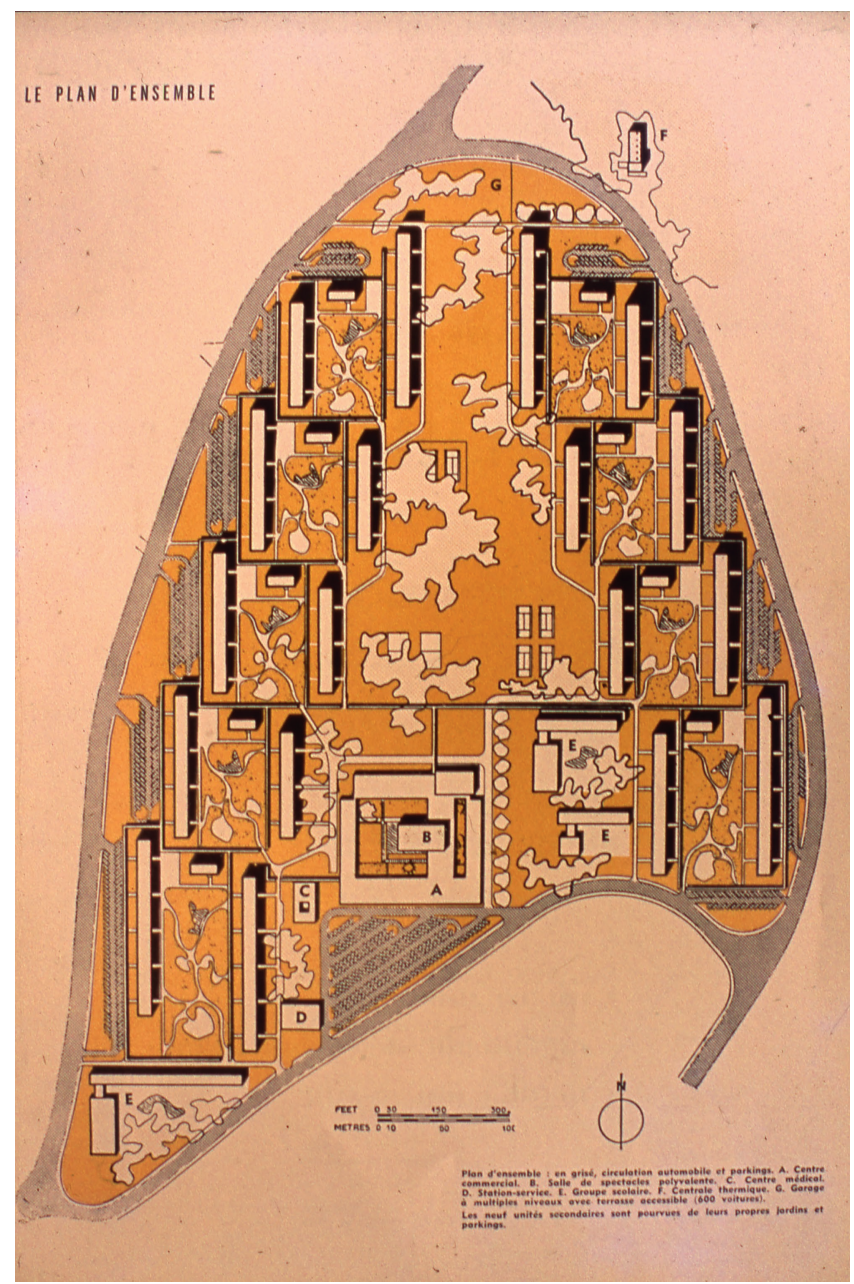

FIGURE 13.3 Marcel Lods, view of the overall plan of the housing estate "Grandes-Terres," Marly-le-Roi, 1952-1960 (Fonds Lods. Académie d'architecture/Cité de l'architecture et du patrimoine/Archives d'architecture du XXe siècle). 
However, the relationship between the town planning project and the actual site is rarely considered. The site is often reduced to an abstract notion of open land, and the vegetation is just a generic element of the design. Some examples are different, however. On the housing estate at Beaulieu-Le Rond-Point in Saint Etienne, the project of the landscaper Jean Marc (1964) involves the careful layout of hedges and opposing hedges and shrubs and trees, which are intended to establish continuities with the surrounding countryside. In Bron-Parilly, Michel and Ingrid Bourne do not use hedges but instead favor large masses of trees (1957), in reference to some of Le Corbusier's work, and at les Minguettes in Vénissieux (1966) they use a central, empty space, introducing lines to separate the different parts of the neighborhood and using hedges to give structure to the surroundings of the buildings. For the Unite de voisinage in La Maurelette (1962), Jacques Sgard integrated elements of the local landscape and used them in a set of tree-lined walkways, paths, and small public squares, creating views toward the nearby bastide and a row of plane trees. However, it is at the ZUP (priority development zone) de Châtillon, near Reims, that the landscape of the project is as powerfully expressive as the buildings. On this site, the landscaper Jacques Simon "reinvents an independent, playful and sensual landscape where man creates the rhythm" (Blanchon-Caillot 2007, p. 16). The open ground then becomes the support for a newly invented geography, intended to cover an abstract state.

\section{The Urban Framework}

It was in the 1960s that the notion of 'green' space appeared, both in regulatory texts and in the landscaping profession. Natural spaces, now recognized as an important subject for urban and regional planning, were given an essential role in developing the large-scale structure of different territories. The landscape designer Théodore Leveau (1896-1971) advocated in 1964 the "necessary introduction of green spaces into the city" corresponding to "a system of green spaces inside the town which are continually integrated as part of the structure of the future city," formed by "a series of green corridors and wooded areas (...) among the housing units" (Laveau 1964, cit. in Toublanc and Bonin 2012, p. 4). In 1964, Jacques Simon considered greenspaces as suitable for hosting games, sports, and leisure activities and that the development of these spaces must be articulated with planning on a regional level (Simon 1964). In the background, there was still the idea of preserving a ring of open space around cities, which would remain free from construction, so as to avoid the creation of a dense and continuous conurbation. At the same time, green corridors would help break up the urban continuum.

The town planning approach that developed in France in the 1970s showed a notable difference when compared to the functionalist approach to urban design. The 1976 masterplan for development and town planning in the Ile-de-France region (Schéma directeur de l'aménagement et de l'urbanisme de la région d'Ile-de-France or SDAURIF), introduced two types of natural spaces - the greenbelt and the green grid (la trame verte). The general function of the greenbelt is to spatially limit urbanization, by reserving land for recreational, landscaping, or ecological functions. The new designation of certain areas as Zones Naturelles d'Equilibre (areas of natural equilibrium) corresponded to this idea. The trame verte refers to the work of Forestier, who integrated agricultural land and forests into his park system. In this masterplan, the trame verte is described as underpinned by emerging environmental and landscape principles: it designates a system of interconnected natural spaces. Even so, ecological concerns were still absent, even though flood-prone areas were recognized as 


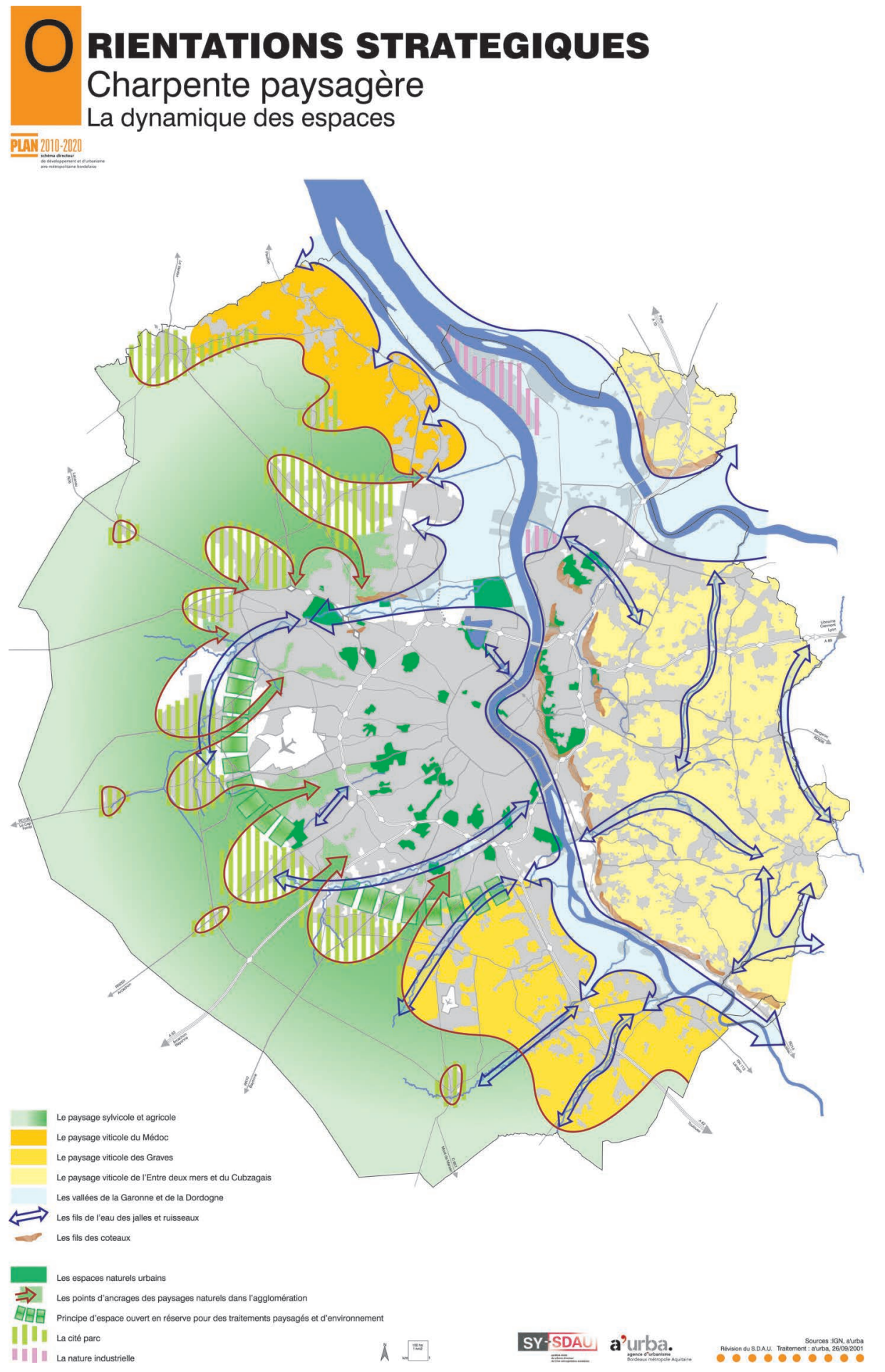

FIGURE 13.4 a'urba, plan 2010-2020, development master plan, landscape framework charter, Bordeaux, 2011 (a'urba, agence d'urbanisme Bordeaux Aquitaine). 
important for waterfowl and migratory birds. Natural spaces were still considered either as landscape to be protected, destined to become a recreational area, or as an agricultural space, destined to be transformed by intensive agriculture. In both cases, the idea was to create reserves but not yet spaces that could determine the organization and morphology of the city. Due to its ability to respond to environmental concerns and to the need for the protection of natural landscapes, from the $1980 \mathrm{~s}$, the notion of the trame verte became a tool for thinking about urban development.

It was the Grenelle de l'Environnement in 2007 that established the obligation to include a green framework (trame verte), complemented by a blue framework (trame bleue), in all planning documents, as a contribution to fighting against the loss of biodiversity. In the masterplan for the Bordeaux Metropolitan Area (2011), the framework of greenspaces included the idea of continuity, encouraging connections within the metropolitan area and in the city center. Every open space is considered to have a specific ecological value, and this ecological value is amplified by the fact that the spaces are connected in a system. They included both major elements (parks, land reserves, rivers, lakes, etc.) or more minor connections (boulevards, linear green areas, watercourses, etc.). It is therefore the idea of a green framework that connects urban design with planning on the regional scale and which defines the spaces between town and country as places of creativity and innovation (Figure 13.4).

\section{The Architecture of the Territory}

Critical reflections on the contemporary city open up a new role for natural spaces, which are seen as a means of redesigning urban areas and of preparing the city for future transformation. The conditions of urban growth at the end of the 20th century and the pressure on natural ecosystems brought about by growing cities and metropolises have fueled research on the renewal of urban development processes. The notion of sustainable development legitimized the ecological and environmental questions that had been present in France since the 1990s. A kind of reversal of meaning has taken place in terms of the design of unbuilt urban spaces: artificial green islands such as parks and gardens, fragments of the town plan that remain unfinished, or expanses of land on the outskirts of cities invaded by a certain wildness today constitute essential spaces. These areas can become the framework for contemporary urban design approaches, allowing them to open up to ecological and environmental considerations.

\section{Recomposing the Territories}

In the contemporary city, natural spaces can be part of strategies for territorial recomposition. This is a need that dates back to the 1970s, with the beginning of a period of reforms for large housing estates and new thinking on the status and morphology of public spaces. In the following projects for urban renovation of social housing neighborhoods, greenspace is a tool for giving them a new urban structure. For example, in the renovation of the housing complex Les Minguettes in Vénissieux (1994-2009) by Antoine Grumbach, the attention given to the site, "a unique place in the geography of Greater Lyon," led to the development of a green framework, composed of a green belt that surrounded the housing complex. Planted avenues were introduced, crossing through the renewed urban fabric, and a continuity of green spaces was developed, within the urban area. 
In metropolitan areas where transformation is happening, natural spaces can be used as a tool for reforming and bringing together fragmented and contradictory urban fabrics. In the key urban area between Paris and Aubervilliers (2003), where there is a concentration of communication infrastructures, residential blocks, tertiary sector buildings, and industrial wastelands, the project by Agence TER is centered around a core 'greening' principal. A shared garden fits into a gap between the buildings, and an 'urban forest' surrounds the infrastructure of the motorway. Nature is here seen as a shared story, making it possible to connect together elements that had until then been in conflict (Figure 13.5).

This is also an idea that is present in the transformation of the Ile de Nantes, an island of 337 hectares once occupied by shipyards, whose transformation makes it possible to imagine a new urban centrality. In 2000, Alexandre Chemetoff, in charge of the project until 2012, proposed an innovative methodology, replacing the traditional masterplan with a 'guide plan'. This is a system of public and green spaces that forms a background structure allowing the development of different future projects, setting in motion a process that can

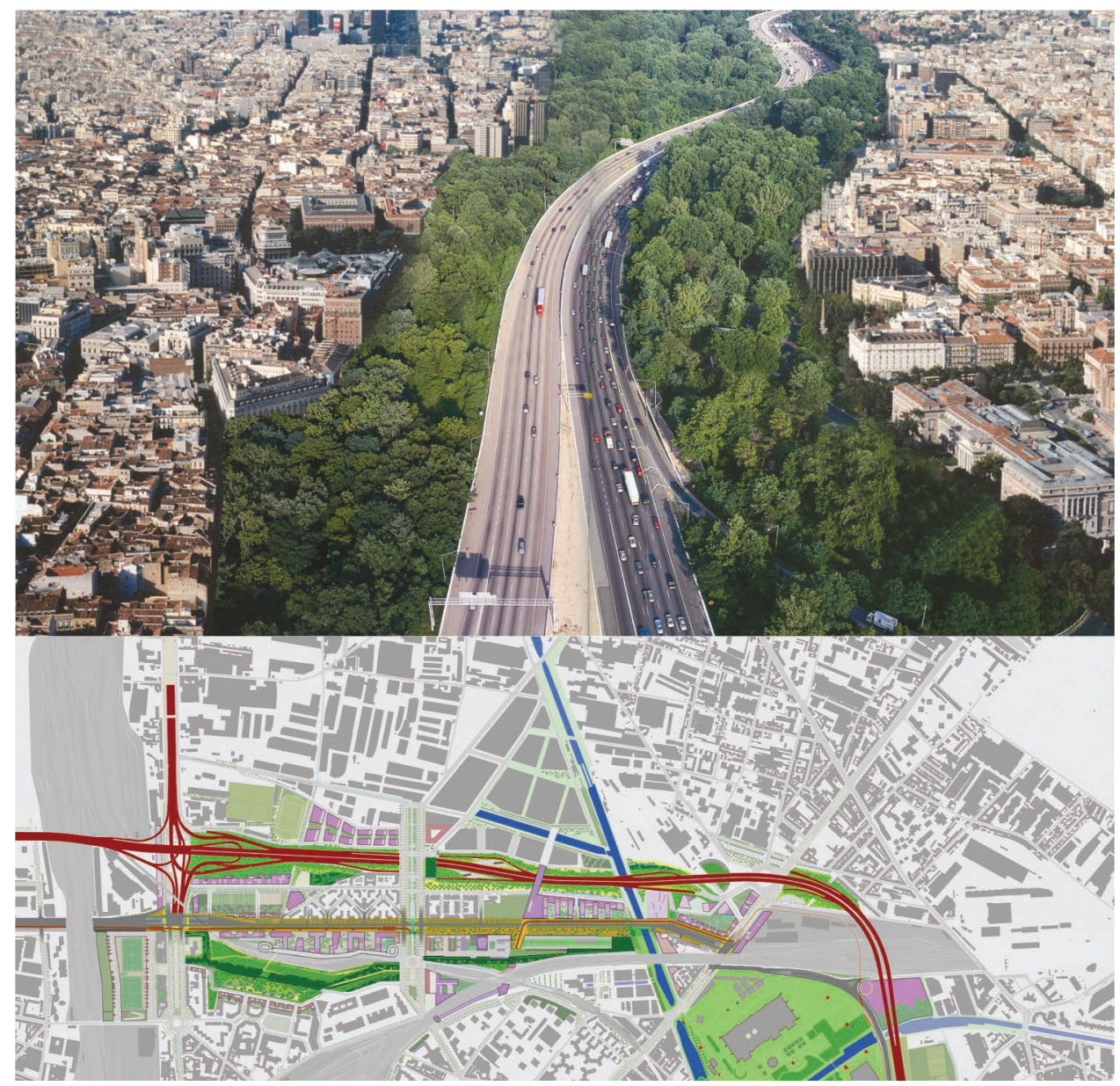

FIGURE 13.5 Agence TER, project for Paris nord-est, 2003 (Agence TER, Paris). 
take place gradually over a long period of time and adjust according to the evolution of the island's identity. After first recognizing the existing heritage of the place and the need to make the area part of the new metropolis, the project proceeded by reclaiming the banks of the Loire, opening up the island to the view of the river, then identifying areas for possible development. The projects for greenspaces in the 'guide plan' form the backdrop for urban transformation. These ideas were continued in 2017 by Jacqueline Osty, who also identified this connection between projects for town planning and green public spaces, as a means of creating a dialogue between large-scale and small-scale approaches. In Nantes, from east to west, a network of public spaces weaves a link between the different districts of the island and creates a continuous walkway between the parks in the west and the urban amenities to the east. This longitudinal green zone is completed by a network running north-south, formed by small paths that create links with the riverbanks on the island. Along the same lines is the Ecoquartier Flaubert project in Rouen, designed by Jacqueline Osty (20092030). In this project, greenspaces are laid out and intersect with transport infrastructure and with fragments of preexisting urban projects, all of which guide the design of the urban fabric. Greenspaces are a central element in the design of the neighborhood, not only because of the transformation of the banks of the Seine into a continuous promenade but also by the intersection of a vertical axis formed by a canal turned into a public park and a horizontal line of public squares and parks (Figure 13.6).

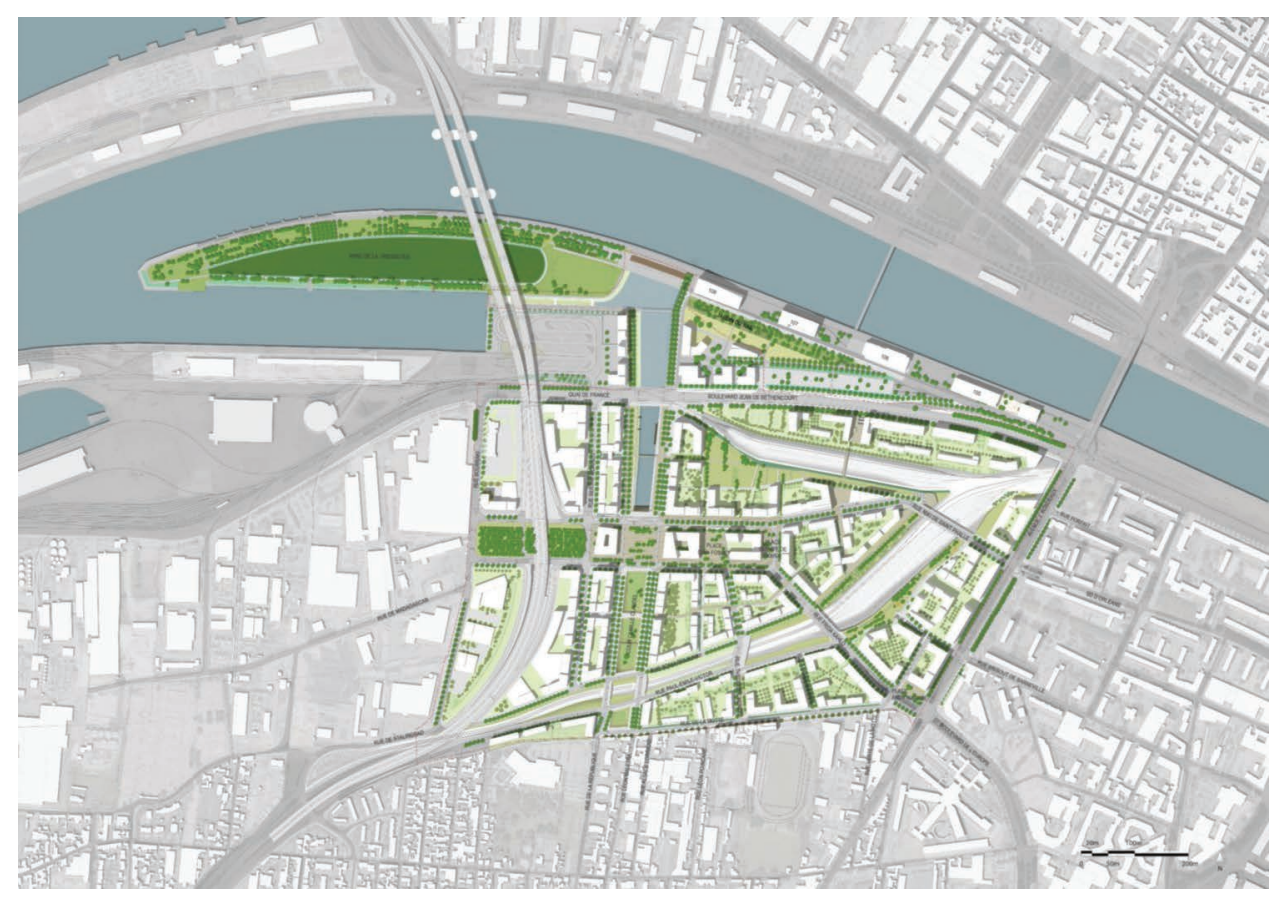

FIGURE 13.6 Jacqueline Osty, plan of the éco quartier Flaubert, Rouen, 2009 (Atelier Jacqueline Osty et Associés, Paris). 


\section{Preparing Territories for Future Uses}

From another perspective, green space acts as a regulating element for built-up areas: it sets the rules for the sites where construction can happen, defines the relationships with the other components of the region, and responds to environmental questions. In the project of Dominique Perrault for the site of the former Unimetal factory in Caen (1994-1997), greenspaces have the capacity to give structure to urban projects, to constitute a kind of substratum, which guides the successive choices for architectural creations. This implies that the development of the urban project lasts for much longer than the architectural work. The urban framework formed by the greenspaces gives the site an immediate structure and, in this way, prepares it for future uses. It is this structuring role of the natural spaces that the surrounding region and town plan legitimize at the architectural level.

At the confluence of the Rhône with the Saone in Lyon, in a site devastated by deindustrialization, the project (1995-ongoing) by François Grether and Michel Desvigne aims to rebuild the urban fabric. A grid formed by the remains of large-scale landscape structures rivers, parks, canals, boulevards - constitutes the basis for drawing up a general framework of natural spaces, in order to organize the new urban fabric. The project follows the gradual mutations of the area, starting from the banks of the Saone and continuing with ramifications perpendicular to the bank on the Rhône. With the framework of natural spaces as a guideline, a two-layer urban landscape develops, in which the two dimensions of the ephemeral and the perennial coexist. From a practical point of view, the strategy is that of an evolving and flexible process, reorganizing the peninsula with greenspace as a core element. The project, which is much more than just a master plan, is a process using different strategies over a 30-year period and can be adapted or challenged by the unpredictable future life of the neighborhood.

In the changing landscape on the right bank of the Garonne, facing the historic city of Bordeaux, Michel Desvignes' project (2001-ongoing) also considers the site through the lens of a long timescale: first through the connection of existing landscape spaces, such as geographic elements along the Garonne, then through the recognition of the remains of old routes and new wastelands (the traces of old plots of land - agricultural and then industrial in strips) that are part of the district, and, finally, maintaining the size of this complex network, which can be looked at on different scales, as a prerequisite for defining construction regulations in the area. The project is unified through a complex grid of greenspaces, where blocks of trees, clearings, and lawns alternate, differentiated by alternate ways of cutting and mowing them and where the addition of concrete platforms allow a variety of uses. The result is a grid made of green corridors, hubs, or parks, which follows the orientation of the river, transforming the disused industrial sites and recreating spaces for biodiversity. This is a network that can adapt to the complexity of contemporary housing principles.

For almost three centuries, natural space in its various forms has been present as an element of urban design. After being considered, first, as an urban system superimposed on the city and determining its development; later, as a substratum for modernist urban design and as a framework for planning; and, finally, as an ecological system for redesigning urban areas and preparing for their future transformation, greenspace has ultimately provided an opportunity to criticize the contemporary city and has become a powerful ingredient for the imagination of new urban forms. 


\section{Bibliography}

Agache D. A., J. M. Auburtin, and E. Redont. 1915. Comment reconstruire nos cités détruites. Notions d'urbanisme s'appliquant aux villes, bourgs et villages. Paris: Armand Colin.

Alphand A. 1867-1873. Les promenades de Paris. Paris: Rothschild.

Arsène-Henry X. 1961. L'art dans les villes nouvelles. Techniques et architecture, 4: 82-83.

Arsène-Henry X. 1969. Notre ville. Tours: Mame.

Benoit-Lévy G. 1904. La cité jardin. Paris: H. Jouve.

Benoit-Lévy G. 1910. La Cité-jardin. La Gazette des beaux-arts, a. 51, 632: 157-168.

Blanchon-Caillot, B. 2007. Pratiques et compétences paysagistes dans les grands ensembles d'habitation, 1945-1975. Strates 13 https://journals.openedition.org/strates/5723.

Descat, S., E. Monin, and D. Siret. 2006. La ville durable au risque de l'histoire. Lille-Paris: ENSAP Lille-Jean-Michel Place.

Eberstadt, R. 1920. Handbuch des Wohnungswesens und der Wohnungsfrage, Jena: Gustav Ficher.

Forestier, J. C. N. 1908. Grandes villes et systèmes de parcs. Paris: Hachette et Cie.

Gutton, A. 1941. La charte de l'urbanisme. Paris: Dunod.

Gutton, A. 1950. Conversation sur l'architecture, 2. Paris: Vincent, Fréal et Cie.

Hénard, E. 1903-1909. Etudes sur les transformations de Paris. Paris: Librairies-imprimeries réunies.

Laugier, M. A. 1755. Essai sur l'architecture. Paris: Duchesne.

Leveau, T. 1964. Les espaces verts dans la cité future. Espaces verts, 1 (December): 13-21.

Le Corbusier. 1943. La charte d'Athènes, Paris: Plon.

Le Corbusier. 1945, 1959. Lurbanisme des trois établissements humains. Paris: Denoël; Paris: Éditions de Minuit.

Loudon, J. C. 1829. Hints for Breathings Places for Metropolis, and for Country Towns and Villages, on fixed Principles. The Gardener's Magazine and Register of Rural \& Domestic Improvement 5, 23 (December): 686-690.

Préfecture du département de la Seine, 1913. Commission d'extension de Paris. Considérations techniques préliminaires (la circulation, les espaces libres). Paris: Imprimerie de Chaix.

Rey, A. A., C. Barde, and J. Pidoux. 1928. La science des plans des villes. Paris-Lausanne: Dunod-Payot.

Risler, G., J. Dépinay, and M. Dufourmantelle. 1916. La question de la reconstruction des villes et villages détruits par la guerre. Paris: Société française des habitations à bon marché.

Sellier, H. s.d. Habitations à bon marché du Département de la Seine (cités-jardins et maisons ouvrières). Paris: Charles Massin.

Simon, J. 1964. La mission du paysagiste. Urbanisme 25, 82-83: 131-135.

Taupin, J. L. 1964. Architecture et urbanisme des groupes d'habitations. In L'urbanisation française, ed. J. Canaux, 129-184. Paris: Centre de recherche d'urbanisme.

The Papers of Frederick Law Olmsted, Supplementary Series, 1. Writings on Public Parks, Parkways, and Park System. 1997. eds. C. E. Beveridge, C. F. Hoffman, and K. Hawkins, Baltimore, MD: Johns Hopkins University Press.

Toublanc, M., and S. Bonin. 2012. Planifier les trames vertes dans les aires urbaines: une alliance à trouver entre paysagisme et écologie. Développement durable et territoires 3, 2 (July) http://journals. openedition.org/developpementdurable/9347.

WCED (World Commission on Environment and Development). 1987. Our Common Future. Oxford: Oxford University Press. 